\title{
Adalékok egy szegedi \\ zsidó munkásszázad történetéhez
}

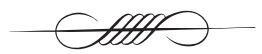

- The Story behind a Jewish Labour Company in Szeged -

DOI 10.14232/belv.2017.2.10

https://doi.org/10.14232/belv.2017.2.10

Cikkre való hivatkozás / How to cite this article: Oláh András Pál (2017): Adalékok egy szegedi zsidó munkásszázad történetéhez. Belvedere Meridionale 29. évf. 2. sz. 163-169. pp

ISSN 1419-0222 (print)

ISSN 2064-5929 (online, pdf)

(Creative Commons) Nevezd meg! - Így add tovább! 4.0 (CC BY-SA 4.0)

(Creative Commons) Attribution-ShareAlike 4.0 International (CC BY-SA 4.0)

www.belvedere-meridionale.hu 


\section{Előszó}

A második világháború után visszatérő zsidók alapvetően szörnyűséges háborús tapasztalatokról tettek tanúbizonyságot. ${ }^{1}$ Példaként elég csak megemlíteni dr. Lőw Lipót, a szegedi prominens zsidó kereskedő esetét, aki ugyan kivételezett helyzetben volt, ezért a deportálást elkerülte, mégis a korábbi élmények miatti elkeseredettségében, meglehetősen zaklatott, olykor egészen szélsőséges hangnemben emlékezett meg az 1944. év történéseiről. ${ }^{2}$

Stein Sándor egykori tartalékos főhadnagy, aki Lőw kivételezett zsidókból álló munkásszázadának ${ }^{3}$ parancsnok-helyetteseként szolgált, a visszaemlékezésében ${ }^{4}$ az előbbivel szöges ellentétben, egy teljesen másféle történetet adott elö. Elmondása alapján a százada több alkalommal megmenekült a szorult helyzetből, jószerencséjük pedig Stein által a század patrónusaként emlegetett Fülöp József vezérkari őrnagy többszöri jóindulatú közbelépése miatt, kitartott a háború végéig. Ezek alapján a 360 fós zsidó munkásszázad veszteség nélkül megúszta a vérzivatart, amely véleményem szerint a vallási, vagy faji hovatartozásra való tekintet nélkül is már csodaszámba tartozik.

1 A visszatérő deportált zsidók élményeinek dokumentálását közvetlenül a harcok elvonultát követően megkezdte az ún. Deportáltakat Gondozó Országos Bizottság (DEGOB). A DEGOB jegyzőkönyvei nagy részét közli a www.degob.hu On-line adatbázis.

2 3618. sz. jkv., www.degob.hu; A jegyzőkönyv Szegeden, dr. Lőw Lipót (Szül.: 1889) Dózsa György u. 16. sz. házában készült 1945. november 18-án.

3 Stein szerint ez a 101/5. Légómentesítési Zsidó Munkásszázad volt. Lőw vallomása szerint ő is ebbe a századba tartozott, tehát Stein a felettese volt Lőwnek.

${ }^{4} \mathrm{Az}$ Emléktöredékek a 101/5. Légómentesitési Zsidó Munkásszázad életéből címmel írt visszaemlékezése Szegeden, 1973. július 31-én kelt, ezt alább teljes terjedelmében közöljük. A visszaemlékezés eredeti példánya Szanka József szegedi gyüjtő tulajdonát képezi, publikálása a tulajdonos tudtával és beleegyezésével történt.
Stein visszaemlékezése nyomán ennek a különleges háborús „sikertörténetnek” kívánok utánajárni.

\section{A zsidók szerepe a szegedi hatósági légoltalomban}

A zsidó származásúak légoltalmi szolgálatra történő behívása 1942-ig általános jelenség volt, sőt a képzett zsidó mérnökök és orvosok fontos láncszemei voltak a szervezetnek. 1942 márciusa után ez a tendencia azonban az ellenkezőjére változott, a munkaszolgálatosokon kívül ezután nem volt sok közük a légoltalomhoz, ugyanis a honvédelmi miniszter 1942. március 27-én kelt 135.133/eln.35.-1942. sz. rendeletével intézkedett a zsidók légoltalmi szervezet vezető beosztásaiból történő eltávolításáról, hivatkozva azok korábbi szabotázscselekményeire. A rendelet szegedi végrehajtása meglehetősen nagy bonyodalmakat okozott, hiszen 1942 novemberében a város hatósági légoltalmának egészségügyi szolgálatosai közül nem kevesebb, mint 300 fö volt zsidó, vagy zsidó származású, illetve a hírvivő, továbbá az egészségügyi mentőszolgálat zsidók által való betöltéséről, illetve be nem töltéséről a rendelet egyáltalán nem is tett említést. A fenti honvédelmi miniszteri rendelet után mégis zömében már csak munkásosztagokban fordulhattak elő zsidók. ${ }^{5}$

Ezekről a munkásszázadokról sajnos nem sok irat, illetve adat maradt meg, háborús tevékenységük rekonstruálása csak nagyvo-

MNL-CSML NB. 30/1945 sz. népbírósági peranyag Dr. Katona István háborús és népellenes büntette tbn. A peranyag között megtalálható a M. Kir. Rendőrség szegedi kapitányságának légoltalmi parancsnoksága. Biz. 4/5- 1942. szám (V.sz.1524/1942.II.o.), Tárgy: Különl. légvéd. szolgálatra igénybevettek megbízhatóság szerint való kiválogatása., Kelt.: Szeged, 1942. november hó 15., valamint M. Kir. Honvédelmi Miniszter 135.133. eln. 35./1942. sz., Tárgy: Különleges légvédelmi szolgálatra igénybevettek megbizhatóság szerint való kiválogatása, Kelt.: Budapest, 1942. évi március hó 27. 
nalakban, vagy érintőlegesen lehetséges. ${ }^{6}$ A legbiztosabb viszonyítási alapot a Szeged város elleni légitámadások története nyújtja. A város elleni 1944. évi amerikai légitámadások okozta romok eltakarításában három zsidókból álló munkásszázad vett részt a hivatalos adatok szerint, ${ }^{7}$ melyek a következőek voltak:

M. kir. 105/301. légó mentési kisegítő munkásszázad

M. kir. 105/31. kisegítő munkásszázad

M. kir. 452. különleges munkásszázad

Sajnos a Stein visszaemlékezésében szereplő 101/5. Légómentesítési Zsidó Munkásszázadról nincs további információm, szerinte a század első parancsnoka Balli Pál tartalékos föhadnagy, a parancsnokhelyettese padig maga Stein Sándor tartalékos fóhadnagy volt, illetve lett volna. A századot 1944. május 5-én, vagy május 8-án állították fel. ${ }^{8}$ A Stein visszaemlékezésében szereplő, Szeged elleni első amerikai, 1944. június 2-iki légitámadás kárainak felszámolásában még csak egyetlen zsidó század vett részt, ${ }^{9}$ ezt töltötték fel a hódmezővásárhelyi munkásokkal. ${ }^{10}$

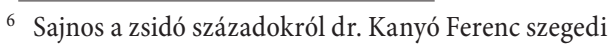
hadtörténész sem tudott adatot feltalálni. Lásd: DuNAINÉ - KANYó 1996.

7 Szeged sz. kir. város polgármestere 31805/1944. sz., Tárgy: A szegedibombatámadások romeltakaritásnál közremüködő munkásszázadok költségeinek elengedése, Kelt: 1944. szeptember 2., MNL-CSML Mérn., Légó. munkaszolgálat szervezése, mentés-romeltakarítás, kármegállapítás c. akta

8 A DEGOB 3618. sz. jkv. és az „Emléktöredékek...” (lásd alább) adatai alapján

9 Szeged sz. kir. város mérnöki hivatala (szám nélk.)/1944.mh.sz. Tárgy: jun. 2. bombatámadás okozta romok eltakarítása., Kelt.: Szeged, 1944. junius 10., MNL-CSML Mérn.

10 Ebben a században szolgált egészen 1944. október 16-ig a hódmezővásárhelyi fényképész, Lusztig Imre is. Lusztig 50 évvel a háború utáni visszaemlékezése szerint a M. kir. 105/301. légó mentési kisegítő munkásszázadban (Lusztig helytelenül 105/301. Légó mentési közérdekű munkaszázadot jelöl meg) teljesített szolgálatot, ahol a századparancsnok, $d r$. Vartai István föhadnagy humánus viselkedésének, valamint annak köszönhetően, hogy Szegeden tudták tartani
Több adat összevetése alapján, valamint a visszaemlékezésben szereplő századra vonatkozó adatok hiányában megállapítom, hogy valójában M. kir. 105/301. légó mentési kisegítő munkásszázadban szolgálhatott a viszszaemlékező. Következésképpen a századokat időközben összevonták, vagy a visszaemlékező már nem emlékezett pontosan az alegységének hadrendi számozására.

\section{Utószó}

A visszaemlékezés forrásértéke elvitathatatlan attól függetlenül is, hogy ha bármelyik feltevésem bizonyítást nyerne. Stein Sándor még ha a századának hadrendi számozásával kapcsolatban esetleg téves adatot is közölt volna, visszaemlékezése nagyon érdekes és értékes adalékokat nyújt a szegedi zsidó munkaszolgálatosok tevékenységére, sorsára, de ugyanígy a szegedi légoltalom és légitámadások történetére vonatkozóan is. Arról se feledkezzünk meg, hogy végső soron a légitámadások kárainak felszámolásával ezek a zsidó munkások emberéleteket és vagyontárgyakat mentettek meg, ezért az utókor hálával tartozik erőfeszítéseikért.

Végül a visszaemlékezés egy nagyon fontos tanúvallomás is, amelyben híven rögzítésre került egy bátor és igaz ember, nevezetesen Fülöp József vezérkari őrnagy (később ezredes) nagyszerü viselkedése. Ez alapján Fülöp József a cselekedeteivel egy zsidó munkaszolgálatos század teljes személyi állományát, sőt több zsidó tartalékos tiszt családját is megmentette a biztos pusztulástól. ${ }^{11}$

$$
\text { -- O -- }
$$

\section{FORRÁSKÖZLEMÉNY}

$$
\text { -- O -- }
$$

a századot, a századból mindenki épségben hazatérhetett. Lusztig visszaemlékezését lásd: KATONA - Lusztig 1995. 183.

11 Példaként lásd a visszaemlékezésben a Nagyváradon lefogott tisztek (Patzauer és társai), vagy akár a hódmezővásárhelyi illetőségű munkaszolgálatosok átvezényléssel történt megmentésének esetét. 


\section{EMLÉKTÖREDÉKEK}

a 101/5. Légómentesítési Zsidó Munkásszázad életéből

Régi reminiszcenciákat, soha el nem múló emlékekkel dús nosztalgiát ébresztett fel bennem a közel napokban Izraelből Szegedre látogató Schlésinger József, volt munkaszolgálatos bajtársam, amikor arra kért, hogy elevenítsem fel az együttesen eltöltött „muszos idők”12 eseményeit. Majd' harminc év távlatából az események sajnos kényszerű és maradandó hatások alapján rögződtek belém.

Hogyan is kezdődött ez a beszélgetés? Az emlékek lapjait visszahajtogatva sok olyan természetű esemény került szóba, jutott felszínre, amelyről századunk sorsának messzebbmenő érdekei miatt a század tagjai természetszerüleg akkor nem tudhattak konkrétumokat, mint ahogy még ma sem tudják sokan, hogy miképpen és milyen körülmények között vészelte át a fasizmus végső napjait 360 munkaszolgálatos a legnehezebb időkben.

A muszosok nem tudták és nem is tudhatták, hogy kinek a segítsége tette lehetővé azt, hogy kivétel nélkül mind a 360 ember megmaradt életben és a felszabaduláskor szerencsésen hazatérhetett otthonába.

Ahogy e szomorú, de mindannyiunknak emlékezetes időkről beszélgetünk, Schlésinger barátom arra kért, hogy emlékezetem szerint vessem papírra a század - úgyszólván egyedülálló - megmenekülésének történetét és ne feledkezzem meg azokról a személyekről sem, akik önzetlen tevékenységükkel, minden érdek nélkül, csupán emberszeretetből mentették meg a pusztulástól a 101/5. Légómentesítési Századot, melyet a szegedi hadtest ${ }^{13} 1944$. május 5.-én ${ }^{14}$ szervezett meg és állított fel a hadtestparancsnokság alá tartozó zsidó munkaszolgálatosokból.

A század eredetileg kb. 250 főből létesült azzal a céllal, hogy a város bombázása által

12 A „musz” jelző a munkaszolgálatos közkeletű mozaikszava volt.

13 A szegedi V. hadtestről van szó.

14 dr. Lőw Lipót vallomása szerint 1944. május 8-án. Lásd: DEGOB 3618. sz. jkv. keletkező romokat takarítsa el és az ezzel kapcsolatos egyéb munkálatokat végezze szükség esetén. A megalakult század első parancsnoka Balli Pál tartalékos főhadnagy volt és helyettese e sorok írója: Stein Sándor tartalékos főhadnagy, aki az első világháborúban nyert kitüntetései alapján, mint kivételezett zsidó tiszt teljesített itt szolgálatot. ${ }^{15}$ A szakaszparancsnokok ugyancsak kivételezett zsidó altisztek voltak. A keretlegénység a rendes katonai szolgálatot teljesítő Tolnai őrmester és még néhány altisztből, tisztesből állott. Hadd jegyezzem itt meg, hogy Balli főhadnagy joviális beállítottságú tisztességes ember volt minden megszokott katonai fölényeskedéstől mentesen. A keretlegénység, ha katonáskodósan durva és szigorú volt is a munkaszolgálatosokkal, tudták, hogy a század legfőbb védelmezője - lehet mondani: patrónusa - a hadtest vezérkari fónöke: Fülöp József vezérkari őrnagy (később vezérkari ezredes) volt.

A századot több ízben akarták a felsőbb szervek Szegedről Ukrajnába vezényelni, de Fülöp őrnagy minden alkalommal megakadályozta ezt. Jómagam aki mint barátja, mindennapos vendége voltam a vezérkari fönöknek, tisztában voltam azzal, hogy Fülöp örnagynak kimondott és eltökélt szándéka a századot átmenteni s a lehetőség szerint a felszabadulásig Szegeden tartani, mely szándéka - szerencsére kitartó céljának és hatalmi energiájának - sikerrel is járt.

E századhoz hívatta be szolgálattételre Patzauer Dezső és Beck Dezső kivételezett tart. föhadnagyokat, dr. Lénárd Pál és Weisz Márton tartalékos hadnagyokat, valamint Fodor Miklós tart. századost. ${ }^{16}$ Ezeket a tiszteket

15 Vö.: dr. Lőw Lipót tanúvallomása /A kiemelések a szerzőtől/ alapján: „(...) 1944. május 8-án régi háborúsérdemeik alapján, akkori törvények szerint 6 zsidó tisztet, engem mint tart. századost, Beck Dezső, Szöreg, Patzauer Dezsö, Szeged, dr. Weisz Márton, Szeged és Lénárt, Szabadka a szegedi bevonulási központ parancsnoksága behívott. (...) Egy (...) század Szegeden meg is alakult, a helyettes parancsnoka Stein Sándor tart. föhadnagy volt." Lásd: DEGOB 3618. sz. jkv.

16 Az eredeti gépelt szövegben zászlós, de ezt Stein tollal áthúzta, és korrigálta századosra. 
eredetileg Szamosújvárra helyezték. Az ottani parancsnokság azonban őket nem vette át, hanem visszaküldte Szegedre Réti Béla tart. honvéd hadnagy kíséretében. Amikor ezek Nagyváradra értek, az állomáson a csendőrség leigazoltatta őket és miután zsidók voltak, bevitték az egész együttest a nagyváradi gettóba. Réti, amikor hazaérkezett, jelentette a történeteket. Ekkor történt az, hogy Patzauer Dezső alkalmazottja, aki Nagyváradra utánament a csoportnak, hazatelefonált Patzauer feleségének, hogy azonnal intézkedjék, mert az ottani gettót harmincezer zsidóval órákon belül nyugatra indítják. ${ }^{17}$ Patzauer Dezső felesége kétségbeesett állapotban felkeresett lakásomon, s panaszát előadva vele együtt felsiettünk a hadtesthez, hogy Fülöp vezérkari főnök segítségét kérjük. A hadtest kapuügyeletesétől telefonáltam fel Fülöphöz kihallgatásért és közöltem vele, hogy egy kétségbeesett aszszonnyal vagyok itt és életekről van szó, tehát szíveskedjék fogadni. Fülöp erre arra kért, hogy este menjek fel a lakására és ott majd megbeszéljük a továbbiakat. Mégis azonnal fogadott $^{18}$ és fel is siettünk Patzauernéval együtt hozzá, ahol az előszobában jelentéseket tenni szándékozó tiszteket találtunk. Fülöp elnézést kért a várakozó referálandó tisztektől azzal, hogy „Stein főhadnagynak sürgős jelenteni valója van.” Midőn előadtam a történteket, Fülöp közvetlen /K/-vonalon ${ }^{19}$ érintkezésbe lépett a nagyváradi gettó csendőrparancsnokával és követelte, hogy a jogtalanul és törvénytelenül befogott és gettóba zárt tiszteket adja ki. A

17 Nagyváradról deportáló vonat indult 1944. május 23-án, május 25-én, május 28-án, május 29-én, május 30-án, június 1-én, június 3-án, június 5 -én és június 27-én SzITA 21-22.

Az első amerikai légitámadás Nagyvárad ellen 1944. június 2-án történt, de akkor a század minden tagja már Szegeden tartózkodott, mivel az ottani romok eltakarítását végezték. A fenti eseménysor tehát 1944. május 25 - június 1. között játszódhatott le.

18 A gépelt szövegben „, megadott időben” szerepel, de ezt tollal korrigálta Stein a fentiek szerint.

19 Stein oldaljegyzete alapján: Katonai Közvetlen vonal csendőralezredes először nem akarta a vezérkari főnök parancsát teljesíteni arra való hivatkozással, hogy az 1944 áprilisában megjelent rendelet ${ }^{20}$ értelmében kivétel nélkül minden zsidót ki kell vinni az országból. A hosszú vitának a vége az lett, hogy Fülöp erélyes közbelépésére a kivételezett, fentebb felsorolt tisztek visszaérkeztek Szegedre. ${ }^{21}$ - Fülöp módját ejtette a magyar hatóságoknál annak is, hogy a kivételezettek családtagjait sem deportálták és lakásuk is érintetlenül maradt. E cselekmény összesen hat családot érintett. ${ }^{22}$ Ebben a saját személyemben is érdekelve voltam, ugyanis 84 éves édesanyám és nővérem érdekében is a német SS-parancsnokságnál szót emelt Fülöp, mire a német parancsnok ehhez hozzá is járult, azonban - állítólag - a magyar hatóságok nem engedélyezték ezt, hivatkozva arra, hogy „családtagnak csak a feleség és a gyermek számít”, s így édesanyámat és nővéremet mégis deportálták. ${ }^{23}$

A szegedi első légi bombatámadás után ${ }^{24}$ Hódmezővásárhelyről 110-120 korosabb munkaszolgálatost helyeztek századunkhoz

20 Erre a kérdéses rendeletre vonatkozóan nincs további adatom.

${ }^{21}$ Az esetet Lőw Lipót teljesen másképpen adta elő a háborút követően: „Bennünket 6 tisztet, valamint megfelelö számú altisztet a szegedi parancsnokság ugyanannyi nem zsidó tiszttel és altiszttel a szamosújvári bevonulási központhoz irányított. A szamosújvári parancsnoksághoz a honvédelmi minisztériumnak megfelelő intézkedése nem jutott el, úgy hogy bennünket zsidókat néhány napi ott tartózkodás után hivatalos menetlevéllel ellátva Szegedre visszaküldtek. (...)" A két visszaemlékezést összevetve nyilvánvaló, hogy ez az eset egyáltalán nem volt olyan egyszerü, mint ahogyan azt Lőw körülírta, és amennyiben Stein az igazat írta le, akkor valószínủleg nem csak azon múlt a zsidó tisztek sorsa, hogy késett egy minisztériumi intézkedés. Lásd DEGOB 3618. sz. jkv.

22 Minden bizonnyal itt a kivételezett zsidó tisztek családjairól van szó.

${ }^{23}$ Szegedről 1944. június 24. - június 28. között indultak a deportáló szerelvények. Szita: 21-22. o. és DEGOB 3555. sz., valamint 3618. sz. jkv.

${ }^{24}$ Helyesen az első amerikai légitámadás, melynek időpontja 1944. június 2 . 
kisegítésre. Ide osztották be Patzauer Dezső, Beck Dezső főhadnagyokat és dr. Lénárd Pál hadnagyot, kik - mint ahogy már fentebb említettem - szintén a kivételezettség jogát élvezték. Az idehelyezettek a Szilléri sugárúti iskolában nyertek elhelyezést, s ugyanolyan gondos ellátásban volt részük, mint nekünk a Dugonics utcai ${ }^{25}$ iskolában és annak közvetlenül szoros tartozéka volt, bár állományilag Hódmezővásárhelyhez tartoztak.

A későbbi idők során a sorozatos bombatámadások megszüntek s így csökkent a munkaszolgálatotok feladata is. Ekkor történt, hogy útnak indították a Vásárhelyen székelő törzs nagy létszámú munkaszolgálatos egységét, melynek kapcsán parancs érkezett hozzánk, hogy a Szilléri sugárúti részleg is vonuljon be Vásárhelyre. ${ }^{26}$ Stern Márton (felszabadulás után a szegedi zsidó hitközség elnöke), aki szintén a jelzett részleghez tartozott, valamiképpen értesült arról, hogy ezt a különítményt Ukrajnába vezénylik és rémülten közölte velem, kihez egyébként is barátság füzött, - a hallottakat. Én azonnal felmentem Fülöp őrnagyhoz és kértem segítségét, támogatását az iránt, hogy ne engedje elvinni ezeket a nagyszámban öreg embereket. Másnap már parancsba is jött, hogy a Szilléri-sugárúti iskolában lévő mintegy 120 öreg muszost a törzs-századhoz, vagyis hozzánk, a (Vásárhelyi sugárúti) századhoz ${ }^{27}$ kell állományba venni, s így kb 360 főre megszaporodott század teljes egészében életben maradt.

Itt kell megemlíteni, hogy a vásárhelyi munkaszolgálatosok Ukrajnába történő indításuk előtt Fülöp a hadtest személyautóján hozta haza, Szegedre és a Légó-századhoz osztotta be $d r$. Feuer Egon sebész föorvost, $d r$. Nagy Samu belgyógyászt, dr. Kaufmann Imre tüdőgyógyászt, valamint $d r$. Polgár István szü-

25 A gépelt szövegben a „Vásárhelyi-sugáruti” iskola szerepelt, de tollal korrigálta az író Dugonics utcai iskolára.

26 Ezek alapján a hódmezővásárhelyieket vissza akarták vonni a saját egységük törzséhez, Hódmezővásárhelyre.

27 Tehát a század szegedi részéhez. lész, egyetemi tanárt, akik ugyancsak mi századunknál Szegeden érhették meg épségben a felszabadulást.

Ide tartozik még annak a körülménynek a felemlítése is, hogy a felszabadulást megelőző 8-10 nappal, ${ }^{28}$ tehát a századnak Szegedről való kivonulása előtt a német SS-alakulat élelmezési parancsnoksága, mely hivatva volt a Szegedi Konzervgyár raktárát kiüríteni és magával vinni, - a munkálatokhoz 100 fő munkaszolgálatost kért századunktól. Természetesen ezeket az embereket is magukkal akarták vinni, ami a biztos halált jelentette volna számukra. Hogy ez mégsem sikerült a német alakulatnak, kizárólag Fodor Imre kivételezett hadapródjelöltnek köszönhető, aki ravasz, de annál bátrabb leleményességgel átmentette az említett száz muszost. ${ }^{29}$

Soha meg nem szűnő hálával és köszönettel tartozik a megmenekült 101/5. légós század minden tagja Fülöp József ${ }^{30}$ vezérkari ezredesnek, aki magas pozíciójában, teljes felelőssége tudatában, még a jelentős személyi veszélyt is vállalva, önzetlenül, emberszeretetből mindenkor talált oly utat és módot, mellyel a szó legnemesebb értelmében a biztos pusztulástól mentette meg az életnek a század mintegy 360 tagját.

Hála illeti Szepesváraljai Alfonz ezredest is, aki ugyancsak könnyített emberi jóságával a muszosok kényszerű életén, de köszönet jár dr. Vártay István ${ }^{31}$ és Balli Pál századparancsnok tart. fóhadnagyoknak ${ }^{32}$ is, akik el nem vakulva

28 1944. szeptember legvégén, vagy október legelején történhetett ez az eset.

29 Sajnos számomra nem ismert Fodor leleményességének története.

30 Sajnos a Fülöp Józsefre vonatkozó igazoló bizottsági iratok számomra nem ismeretesek, azonban nem találtam háború után keletkezett nyomozati aktáját sem a levéltári kutatásaim során.

31 Lusztig Imre fentebbi visszaemlékezésében századának parancsnokaként dr. Vartai István föhadnagyot említette! A két név valószínűleg azonos személyt jelölt.

32 Értsd: tartalékos főhadnagyok 
a fasiszta és nyilas dogmák durrogó petárdáitól, emberek tudtak maradni és emberségesen bánni az alájuk rendelt emberekkel.

Végül engedtessék meg szerényen megemlíteni, hogy én, mint az első világháborúban szerzett jog alapján kivételezett tart. föhadnagy és századparancsnok-helyettes a zsidó sors és közösségi érzés mindenkori szemelőtt tartásával igyekeztem a lehetőségeimhez képest segíteni muszos bajtársaim sorsán felhasználva azt a baráti kapcsolatot, mely Fülöp József vk. ${ }^{33}$ ezredeshez és a többi feletteseimhez füzött.

*

Szeged, 1973. július hó 31-én.

(Olvasható aláírás)

/Stein Sándor/

\section{FELHASZNÁLT IRODALOM}

Katona lajos - Lusztig Imre (1995): A második világháborúból hazatérthódmezövásárhelyiek 1945 - 1995. Hódmezővásárhely, Második Világháborús Emlékbizottság.

Dunainé Bognár Júlia - Kanyó Ferenc (1996): A második világháború szegedi hősei és áldozatai, Tanulmányok Csongrád Megye Történetéből XXIII. kötet, Szeged.

Szita Szabolcs (1991): Utak a pokolból. Kecskemét, Petőfi Nyomda Rt.

\section{LEVÉLTÁRI FORRÁSOK}

MNL-CSML NB. Magyar Nemzeti Levéltár Csongrád Megyei Levéltára, Népbíróság iratai.

MNL-CSML Mérn. Magyar Nemzeti Levéltár Csongrád Megyei Levéltára, Szeged város Mérnöki Hivatalának iratai.

33 Értsd: vezérkari ezredes 